\title{
PENGARUH UMUR POHON, BONITA DAN POSISI AKSIAL BATANG TERHADAP STRUKTUR MAKROSKOPIS DAN KUALITAS KAYU JATI SEBAGAI BAHAN FURNITUR (Effect of Tree Age, Site Quality Index and Trunk Axial Position on Macroscopic Structure and Quality of Teak Wood as a Furniture's Raw Material) \author{
dan Johanes Pramana Gentur Sutapa
} \\ Yustinus Suranto*, Tibertius Agus Prayitno, Djoko Marsono
}

\author{
Fakultas Kehutanan, Universitas Gadjah Mada, Jl. Agro no 1. Bulaksumur, Yogyakarta 55281. \\ *Penulis korespondensi. No Tel: 0274-550541. Email: suranto@ugm.ac.id.
}

Diterima: 1 Juli 2014

Disetujui: 9 Desember 2014

\begin{abstract}
Abstrak
Penggunaan kayu jati muda merupakan solusi alternatif terhadap terbatasnya ketersediaan bahan baku yang dihadapi oleh industri mebel. Kayu muda cenderung memiliki kayu berkualitas rendah. Salah satu pengukur kualitas kayu adalah sifat struktur makroskopik. Penelitian bertujuan untuk mengetahui pengaruh umur pohon, bonita dan posisi aksial batang terhadap struktur makroskopis kayu dan kualitas kayu. Tiga puluh enam pohon jati muda ditebang dari kawasan hutan KPH Kendal, Provinsi Jawa Tengah. Tiga cakram berketebalan $3 \mathrm{~cm}$ diambil dari masing-masing posisi aksial batang, yaitu bagian pangkal, tengah dan ujung. Pengukuran proporsi kayu teras dan dimensi lingkaran tahun dilakukan berdasarkan perbedaan warna alami dan dengan menggunakan lembaran plastik transparan bergambar pola milimeter. Data dianalisis dengan analisis varians dalam rancangan acak lengkap berblok yang disusun secara faktorial. Pengujian lanjutan dilakukan dengan uji HSD Duncan. Kualitas kayu ditentukan dengan analisis determinan berdasarkan kurva normal Z. Hasil penelitian menunjukkan bahwa interaksi tiga faktor tidak berpengaruh terhadap proporsi kayu teras, dan dimensi lingkaran tahun. Interaksi kelas umur dan bonita pengaruh nyata terhadap proporsi kayu teras dan dimensi lingkarah tahun. Posisi aksial batang berpengaruh secara nyata terhadap proporsi kayu teras dan berpengaruh sangat nyata terhadap dimensi lingkaran tahun. Semakin mendekat pada posisi pangkal batang, semakin tinggi proporsi kayu teras dan dimensi lingkaran tahun. Interaksi tiga faktor yaitu kelas umur $\mathrm{V}$, bonita 4 dan posisi tengah batang menghasilkan kualitas kayu tertinggi, yaitu kelas 2, dan interaksi kelas umur V, bonita 3 dan bagian ujung batang menghasilkan kualitas terendah, yaitu kelas 4. Penggunaan kayu berbasis kualitas akan memaksimalkan nilai guna dan meningkatkan umur pakai produk, sehingga mengurangi intensitas penebangan hutan dan lebih ramah lingkungan hidup.
\end{abstract}

Kata kunci: bonita, kualitas kayu, posisi aksial batang, struktur kayu, umur pohon.

\begin{abstract}
Young teak utilization is an alternative solution of limited raw materials faced by furniture industry. Young wood tends to have a low-quality wood. One element for measuring wood quality is wood macroscopic structure properties. This study was aimed to determine the effect of tree age, site quality index and axial stem position on wood structures and wood quality. Thirty-six young teak trees were harvested on forest areas of Kendal Forest District, Central Java Province. Three disks were taken from each trunk, namely from the butt, middle and upper parts. Heartwood proportion and annual ring dimensions were measured based on natural color difference by using millimeter grid apparatus. Data were analyzed by using variance analysis arranged in blocked factorial and further testing were performed by using HSD Duncan. Wood quality was analyzed using determinant method which elaborated based on Z norm curve. Results showed that interaction of three factors did not affect on heart-wood proportion and growth ring dimensions. Interaction of age classes and site quality index influence significantly on heart-wood proportion and growth ring dimensions. Stem axial position significantly affects on heart-wood proportion and very significantly effect on growth ring dimensions. The lower wood position, the higher heart-wood proportion and the wider growth ring dimensions. Interaction of three factors namely class age $V$, site quality index 4 and middle trunk position has a highest wood quality, namely class 2, but interaction of age class $V$, site quality index 3 and top trunk has the lowest one, namely class 4 . The use of wood-based quality will maximize the value and increase the product lifespan, thereby reducing the intensity of logging and become more environmental friendly.
\end{abstract}

Keywords: axial position, plant ages, site quality index, wood structure, wood quality.

\section{PENDAHULUAN}

Permasalahan yang dihadapi oleh sektor produksi kehutanan dan industri hasil hutan dapat dibedakan menjadi 4 kelompok. Pertama, kelangkaan ketersediaan bahan baku industri hasil hutan, baik secara kualitatif maupun kuantitatif. Kedua, peningkatan beaya proses produksi 
kehutanan dan industri hasil hutan. Ketiga, kompetisi yang lebih ketat pada era globalisasi yang mewajibkan penerapan standar-standar proses produksi dan skema sertifikasi pemasaran ekspor ke manca-negara. Keempat, penurunan kualitas lingkungan hidup berupa pencemaran udara, air dan tanah yang menimbulkan pemanasan global, hujan asam, banjir dan longsor, perubahan iklim regional dan global, disharmonitas ekosistem kehidupan serta perubahan siklus hidup flora dan fauna. Permasalahan tersebut perlu diatasi oleh berbagai sektor secara serentak. Bagi sektor kehutanan dan industri hasil hutan, cara mengelaborasinya dilakukan antara lain dengan maksimalisasi pemanfaatan bahan baku kayu hasil hutan tanaman, peningkatan efisiensi pemesinan kayu, peningkatan kualitas produk dan muatan teknisnya, perbaikan kebijakan managemen hutan lestari, harmonisasi terhadap standar kualitas produksi, dan mengarahkan proses produksi yang lebih ramah lingkungan hidup (Tan dkk., 2007).

Sebagai bagian dari produksi kehutanan dan industri hasil hutan, industri mebel berbahan kayu jati di Provinsi Jawa Tengah menghadapi banyak kendala, salah satu yang dominan adalah keterbatasan ketersediaan kayu berkualitas tinggi yang dihasilkan dari penebangan pohon dari hutan tanaman yang berumur tua (Seno, 2008). Problematika ini diatasi dengan cara penggunaan kayu secara menyeluruh, baik dari bagian pangkal, tengah maupun ujung batang pohon yang dihasilkan dari pemanenan hutan jati rakyat maupun dari penjarangan hutan negara yang dikelola Perum Perhutani (Gadas, 2005). Aktivitas penjarangan dilakukan secara periodis terhadap hutan jati, antara lain terhadap kelas umur 3, 4 dan 5. Kayu yang dihasilkannya cenderung memiliki kualitas kayu yang rendah sebagai kayu konstruksi, termasuk konstruksi mebel (Moore dkk., 2009). Sementara itu, terdapat keragaman yang tinggi dalam hal bonita di dalam kawasan hutan jati (Wulffing, 1932). Perbedaan tingkat bonita atau kesuburan tanah berpengaruh terhadap tingkat kecepatan pertumbuhan pohon, yang pada gilirannya berpengaruh terhadap kualitas kayu yang dihasilkan (Zobel dan Buijtenen, 1989; Moore dkk., 2009).

Kualitas kayu merupakan cerminan tingkat kesesuaian antara sifat-sifat kayu dengan tuntutan persyaratan yang diperlukan bagi penggunaan tertentu atas kayu tersebut. Semakin sesuai sifatsifat kayu terhadap tuntutan persyaratan bagi penggunaan tertentu kayu, semakin tinggi tingkat kualitas kayu tersebut (Prayitno, 2005). Sifat-sifat kayu meliputi sifat-sifat dasar kayu dan sifat-sifat pengolahan kayu. Sifat dasar kayu meliputi sifat kimia kayu, sifat struktur makroskopis kayu, sifat anatomi kayu, sifat fisika kayu, sifat mekanika kayu (Wanneng, 2011), sedangkan sifat pengolahan kayu meliputi sifat pengeringan kayu, sifat pengawetan kayu, sifat pemesinan kayu (Etele dan Magoss, 2013) dan sifat perekatan kayu serta sifat reka-oles (finishing) kayu. Sifat struktur makroskopis kayu yang mencakup proporsi kayu teras dan dimensi lebar lingkaran tahun merupakan parameter penting untuk menentukan kualitas kayu bagi penggunaannya sebagai bahan furnitur. Semakin besar proporsi proporsi kayu teras, semakin tinggi kualitas kayu (Darwis dkk., 2005). Semakin lebar dimensi lingkaran tahun, semakin rendah kualitas kayu sebagai bahan furniture (Bath dan Indira, 1997). Oleh karena itu, kedua parameter ini merupakan hal yang sangat penting untuk diketahui, sehingga pengujian terhadap kedua parameter ini perlu dilakukan dan kontribusinya terhadap penentuan kualitas kayu perlu diungkap.

Penelitian ini bertujuan untuk mencapai empat hal. Tujuan pertama adalah untuk mengetahui pengaruh faktor-faktor: umur pohon, bonita dan posisi aksial batang serta interaksinya terhadap proporsi kayu teras dan dimensi lingkaran tahun pada kayu jati. Tujuan kedua yakni menentukan kualitas kayu jati sebagai bahan furniture berdasarkan proporsi kayu teras dan lebar lingkaran tahun. Berikutnya adalah dapat mencari kombinasi optimal pada ketiga faktor tersebut terhadap kualitas kayu jati dan dapat mengarahkan pemanfaatan kayu dalam rangka mendukung pelestarian hutan produksi dan lingkungan hidup.

\section{METODE PENELITIAN}

\section{Bahan Penelitian}

Bahan penelitian berupa pohon jati muda sebanyak 36 batang yang ditebang dari 36 petak pada kawasan hutan KPH Kendal, Perum Perhutani Unit I Jawa Tengah. Pohon sebanyak 36 batang mewakili tiga aras kelas umur (yaitu III, IV dan V) dan empat aras bonita (yaitu 3, 3,5, 4 dan 4,5) dengan tiga kali ulangan pada setiap kombinasi perlakuan.

\section{Prosedur Penelitian}

Penelitian diawali dengan pemilahan petakpetak hutan yang terkatagori sebagai kelas umur III, IV dan V dari hutan di dalam kawasan hutan KPH Kendal dengan koordinat $06^{\circ} 51^{\prime} 22^{\prime \prime}$ LS sampai dengan $07^{\circ} 07^{\prime} 17^{\prime \prime} \mathrm{LS}$ dan $109^{\circ} 43^{\prime} 28^{\prime \prime} \mathrm{Bt}$ smapi dengan $110^{\circ} 24^{\prime} 35^{\prime \prime}$ BT. Petak-petak ini tercatat di dalam buku Register Inventarisasi Hutan (Model RPKH - PDE2) Bagian Hutan (BH) Subah, BH Kalibodri, BH Kaliwungu, KPH Kendal, Perum Perhutani Unit I Jawa Tengah. Pemilahan lebih lanjut adalah berdasarkan tingkat bonita terhadap 
petak-petak hutan yang menjadi anggota populasi hutan berkelas umur III, kemudian diambil petakpetak yang termasuk ke dalam empat kelompok bonita, yaitu kelompok bonita: 3, 3,5, dan 4, serta 4,5. Aktivitas yang sama juga dilakukan terhadap kelas umur IV dan V. Dengan demikian, secara keseluruhan terpilah 12 kelompok petak hutan. Selanjutnya dilakukan pemilihan tiga petak dari setiap 12 kelompok itu, sehingga diperoleh 36 petak yg menjadi sumber bahan penelitian. Pemilihan didasarkan pada nilai-nilai penting dengan urutan: status kelas hutan (KU, TJBK, TBPTH, HLT), tahun tanam dan kerapatan tegakan (Dkn). Rekapitulasi petak-petak Hutan Terpilih disajikan pada Tabel 1 .

Tahapan berikutnya adalah melakukan inventarisasi dengan mengukur keliling batang setinggi dada terhadap pohon-pohon dalam setiap petak hutan terpilih. Inventarisasi dilakukan dengan menggunakan metode petak ukur berbentuk lingkaran dengan jari-jari $17,8 \mathrm{~m}$, sehingga luas setiap petak ukur adalah 0,1 ha. Intensitas sampling ditentukan sebesar 2,5\%.

Selanjutnya dilakukan perhitungan nilai ratarata keliling pohon pada pada setiap petak ukur. Nilai rata-rata dijadikan dasar untuk menentukan pohon sampel dari petak tersebut. Pohon sampel ditebang dari petak tersebut. Penebangan didahului oleh pemberian tanda dengan menggunakan cat warna merah pada kulit batang yang menghadap ke arah utara dan cat warna kuning pada kulit batang yang menghadap ke arah timur. Kemudian dilakuan pembagian batang bebas cabang menjadi bagian pangkal batang, tengah batang dan ujung batang. Setelah itu dilakukan pemotongan setiap posisi batang bebas cabang untuk mendapatkan cakram (disk) berukuran $3 \mathrm{~cm}$ arah longitudinal batang. Secara keseluruhan, diperoleh 36 × $3=108$ cakram. Setiap cakram diberi notasi tentang nomor pohon,

Tabel 1. Rekapitulasi petak-petak hutan terpilih sebagai sumber bahan penelitian.

\begin{tabular}{cccccc}
\hline No & $\begin{array}{c}\text { Kelas } \\
\text { umur }\end{array}$ & Bonita & \multicolumn{3}{c}{$\begin{array}{c}\text { Petak hutan sebagai } \\
\text { ulangan }\end{array}$} \\
\cline { 3 - 6 } & & & 1 & 2 & 3 \\
\hline 1 & III & 3 & $36 \mathrm{D} 2$ & $36 \mathrm{E}$ & $89 \mathrm{C}$ \\
2 & III & 3,5 & $43 \mathrm{O}$ & $3 \mathrm{H}$ & $56 \mathrm{~J}$ \\
3 & III & 4 & $33 \mathrm{~A}$ & $33 \mathrm{C}$ & $37 \mathrm{D}$ \\
4 & III & 4,5 & $11 \mathrm{~A}$ & $14 \mathrm{~B}$ & $4 \mathrm{~J}$ \\
5 & IV & 3 & $6 \mathrm{C}$ & $36 \mathrm{D} 1$ & $37 \mathrm{~A}$ \\
6 & IV & 3,5 & $43 \mathrm{~J}$ & $94 \mathrm{H}$ & $29 \mathrm{C}$ \\
7 & IV & 4 & $26 \mathrm{C}$ & $36 \mathrm{G}$ & $36 \mathrm{H}$ \\
8 & IV & 4,5 & $46 \mathrm{G}$ & $14 \mathrm{C}$ & $17 \mathrm{~A}$ \\
9 & V & 3 & $18 \mathrm{C}$ & $18 \mathrm{~A}$ & $6 \mathrm{H}$ \\
10 & V & 3,5 & $41 \mathrm{C}$ & $96 \mathrm{~A}$ & $95 \mathrm{~A}$ \\
11 & V & 4 & $5 \mathrm{C}$ & $28 \mathrm{C}$ & $65 \mathrm{E}$ \\
12 & V & 4,5 & $64 \mathrm{~B}$ & $19 \mathrm{E}$ & $66 \mathrm{~A}$ \\
\hline
\end{tabular}

bagian kayu dalam batang serta tanda yang menyatakan orientasi arah utara (Gambar 1 (a) dan (b)). Pada permukaan cakram dilakukan pengampelasan dan pengukuran terhadap proporsi kayu teras berbasis garis demarkasi (Githiomi dan Dougal, 2012) dan dimensi lebar lingkaran tahun setiap cakram. Pengukuran dilakukan dengan menggunakan plastik-transparansi-bergambar-polamilimeter (Gambar 1(c)).

\section{Analisis Hasil Penelitian}

Penelitian melibatkan tiga faktor, yaitu kelas umur, bonita dan posisi kayu dalam arah aksial batang bebas cabang. Faktor kelas umur mencakup tiga aras, yaitu kelas umur III, IV dan V. Faktor bonita mencakup empat aras, yaitu bonita 3, 3,5, 4 dan 4,5. Faktor posisi kayu mencakup tiga aras, yaitu bagian pangkal, tengah dan ujung batang. Ulangan tiga kali bagi setiap kombinasi perlakuan. Dengan demikian, diperoleh 108 unit.

Analisis hasil dilakukan dengan analisis varians di dalam rancangan acak lengkap berblok yang disusun secara faktorial (Zakamouline dan Koekebakker, 2008). Apabila ditemukan adanya pengaruh faktor perlakuan dan interaksinya, maka dilakukan pengujian lanjut dengan menggunakan uji HSD (Honestly Significant Defferent) Duncan. Analisis diskriminan berbasis kurva normal $\mathrm{Z}$ digunakan untuk menentukan peringkat kualitas kayu yang dibedakan menjadi lima wilayah, sehingga ada lima kelas kualitas kayu.

Kurva normal $\mathrm{Z}$ yang dibagi menjadi lima wilayah dengan kriteria sebagai berikut. Wilayah 1 berada pada posisi dengan nilai $Z_{1}<-1,5$. Wilayah

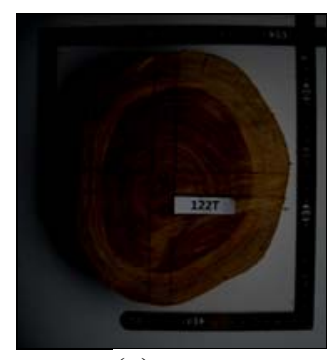

(a)

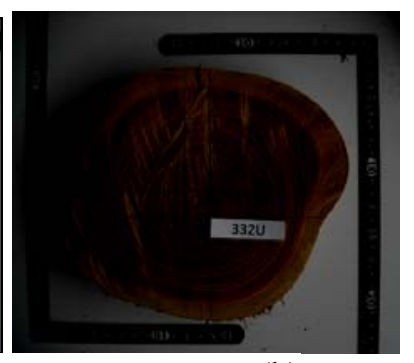

(b)

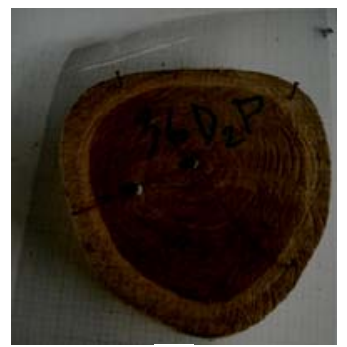

(c)

Gambar 1. Penampang melintang batang (a) KU III, bonita 3,5, posisi tengah, ulangan 2 (b) $\mathrm{KU} \mathrm{V}$, bonita 4,5, posisi ujung, ulangan 2. (c) Pengukuran kayu teras dan lingkaran tahun. 
2 berada pada posisi dengan nilai $\mathrm{Z}$ adalah $-1,5 \leq$ $Z_{2}<-0,5$. Wilayah 3 berada pada posisi dengan nilai $Z$ adalah $-0,5 \leq Z_{3}<+0,5$. Wilayah 4 berada pada posisi dengan nilai $\mathrm{Z}$ adalah $+0,5 \leq \mathrm{Z}_{4}<+$ 1,5 . Wilayah 5 berada pada posisi dengan nilai $Z$ adalah $Z_{5}>+1,5$.

Nilai $Z$ masing-masing sampel dihitung dengan rumus: $\mathrm{Zi}=\{(\mathrm{Xi}-\mu) / \sigma\}$. Notasinya adalah sebagai berikut. $\mathrm{Zi}$ adalah nilai $\mathrm{Z}$ pada pengamatan $\mathrm{ke}-\mathrm{i}, \mathrm{Xi}$ adalah nilai pengamatan terhadap sampel ke-i, $\mu$ adalah nilai rata-rata dari seluruh sampel dan $\sigma$ adalah standar deviasi masing-masing nilai $\mathrm{Z}$ terhadap nilai rata-rata pengamatan.

\section{HASIL DAN PEMBAHASAN}

\section{Proporsi Kayu Teras dan Dimensi Lingkaran Tahun}

Hasil penelitian mengenai proporsi kayu teras dan dimensi lebar lingkaran tahun disajikan secara berurutan di dalam Tabel 2 dan 3. Untuk mengetahui pengaruh kelas umur, bonita, dan posisi aksial dalam batang serta interaksi antara faktorfaktor tersebut terhadap proporsi kayu teras dan dimensi lebar lingkaran tahun, dilakukan analisis varians. Hasilnya disajikan secara berurutan dalam Tabel 4 dan 5.

Dari analisis varians pada Tabel 4 terlihat, bahwa interaksi kelas umur dan bonita berpengaruh

Tabel 2. Proporsi kayu teras (\%).

\begin{tabular}{|c|c|c|c|c|c|c|}
\hline \multirow[t]{2}{*}{ Kelas umur } & \multirow[t]{2}{*}{ Bonita } & \multicolumn{3}{|c|}{ Posisi contoh uji } & \multirow[t]{2}{*}{ Rata-rata } & \multirow[t]{2}{*}{ Standar deviasi } \\
\hline & & Pangkal & Tengah & Ujung & & \\
\hline III & 3 & 55,00 & 52,64 & 54,29 & 53,98 & 2,10 \\
\hline III & 3,5 & 53,72 & 48,34 & 49,52 & 50,53 & 4,90 \\
\hline III & 4 & 70,65 & 63,08 & 65,05 & 66,26 & 6,80 \\
\hline III & 4,5 & 56,27 & 52,54 & 45,00 & 51,27 & 9,94 \\
\hline IV & 3 & 64,01 & 63,36 & 62,68 & 63,35 & 1,15 \\
\hline IV & 3,5 & 79,83 & 74,07 & 74,07 & 76,12 & 5,77 \\
\hline IV & 4 & 73,42 & 72,77 & 63,59 & 69,93 & 9,52 \\
\hline IV & 4,5 & 77,75 & 75,26 & 76,00 & 76,34 & 2,21 \\
\hline V & 3 & 66,50 & 58,21 & 57,03 & 60,58 & 8,94 \\
\hline V & 3,5 & 81,13 & 79,66 & 80,76 & 80,51 & 1,32 \\
\hline V & 4 & 76,28 & 74,88 & 69,65 & 73,60 & 6,05 \\
\hline V & 4,5 & 83,07 & 77,97 & 77,26 & 79,44 & 5,49 \\
\hline \multicolumn{7}{|c|}{ Tabel 3. Dimensi lebar lingkaran tahun (mm). } \\
\hline \multirow[t]{2}{*}{ Kelas umur } & Bonita & \multicolumn{3}{|c|}{ Posisi contoh uji } & Rata-rata & Standar deviasi \\
\hline & & Pangkal & Tengah & Ujung & & \\
\hline III & 3 & 3,641 & 3,130 & 2,645 & 3,139 & 0,86 \\
\hline III & 3,5 & 3,108 & 2,769 & 2,289 & 2,722 & 0,71 \\
\hline III & 4 & 3,089 & 2,764 & 2,993 & 2,949 & 0,29 \\
\hline III & 4,5 & 3,613 & 2,477 & 2,118 & 2,756 & 1,35 \\
\hline IV & 3 & 3,814 & 3,534 & 3,677 & 3,675 & 0,24 \\
\hline IV & 3,5 & 3,495 & 3,288 & 3,160 & 3,314 & 0,29 \\
\hline IV & 4 & 3,738 & 3,397 & 3,086 & 3,407 & 0,56 \\
\hline IV & 4,5 & 4,575 & 4,354 & 4,047 & 4,326 & 0,46 \\
\hline $\mathrm{V}$ & 3 & 7,051 & 4,976 & 5,223 & 5,750 & 1,96 \\
\hline V & 3,5 & 4,345 & 4,271 & 4,491 & 4,369 & 0,19 \\
\hline V & 4 & 3,306 & 2,865 & 2,544 & 2,905 & 0,66 \\
\hline V & 4,5 & 3,273 & 3,723 & 2,873 & 3,290 & 0,74 \\
\hline
\end{tabular}

Tabel 4. Analisis varians proporsi kayu teras.

\begin{tabular}{lrrrrr}
\hline Sumber variasi & DB & Jumlah kuadrat & Rata-rata kuadrat & F hitung & \multicolumn{1}{l}{ Sign } \\
\hline Blok & 2 & 705,69 & 352,84 & $5,60^{* *}$ & 0,0055 \\
Kelas umur (KU) & 2 & 6996,16 & 3498,08 & $55,56^{* *}$ & 0,0001 \\
Bonita (B) & 3 & 2051,17 & 683,72 & $10,86^{* *}$ & 0,0001 \\
KU*bonita & 6 & 2679,15 & 446,53 & $7,09^{* *}$ & 0,0001 \\
Posisi aksial batang & 2 & 516,49 & 258,24 & $4,10^{*}$ & 0,0207 \\
KU*posisi & 4 & 18,77 & 4,69 & $0,07 \mathrm{~ns}$ & 0,9897 \\
Bonita*posisi & 6 & 82,59 & 13,76 & $0,22 \mathrm{~ns}$ & 0,9696 \\
KU*bonita*posisi & 12 & 281,61 & 23,47 & $0,37 \mathrm{~ns}$ & 0,9690 \\
Error & 72 & 4407,27 & 62,96 & & \\
Total & 107 & 17738,92 & & & \\
\hline
\end{tabular}


Tabel 5. Analisis varians rata-rata lebar lingkaran tahun ( $\mathrm{mm})$.

\begin{tabular}{llrrrl}
\hline \multicolumn{1}{c}{ Sumber variasi } & DB & Jumlah kuadrat & Rata-rata kuadrat & \multicolumn{1}{c}{ F hitung } & Sign \\
\hline Blok & 2 & 6,399 & 3,199 & $4,52^{*}$ & 0,0142 \\
Kelas umur (KU) & 2 & 26,519 & 13,259 & $18,75^{* *}$ & $<, 0001$ \\
Bonita & 3 & 17,229 & 5,743 & $8,12^{* *}$ & 0,0001 \\
KU*Bonita & 6 & 33,355 & 5,559 & $7,86^{* *}$ & $<, 0001$ \\
Posisi aksial batang & 2 & 8,206 & 4,103 & $5,80^{* *}$ & 0,0047 \\
KU*Posisi & 4 & 0,669 & 0,167 & $0,24 \mathrm{~ns}$ & 0,9167 \\
Bonita*Posisi & 6 & 2,195 & 0,366 & $0,52 \mathrm{~ns}$ & 0,7933 \\
KU*Bonita*Posisi & 12 & 6,352 & 0,529 & $0,75 \mathrm{~ns}$ & 0,6996 \\
Error & 72 & 49,508 & 0,703 & & \\
Total & 107 & 150,434 & & & \\
\hline
\end{tabular}

Tabel 6. Analisis HSD duncan interaksi kelas umur dan bonita bagi kayu teras (\%).

\begin{tabular}{ccccccc}
\hline \multirow{2}{*}{ Kelas umur } & \multicolumn{4}{c}{ Bonita } & \multirow{2}{*}{ Rata-rata } & Nilai duncan \\
\cline { 2 - 4 } & 3 & 3,5 & 4 & 4,5 & & $(\mathrm{D})$ \\
\hline III & $53,98 \mathrm{fg}$ & $50,52 \mathrm{~g}$ & $66,26 \mathrm{cde}$ & $51,27 \mathrm{~g}$ & $55,51 \mathrm{q}$ & D umur $1 \%=3,96$ \\
IV & $63,35 \mathrm{de}$ & $76,12 \mathrm{ab}$ & $69,93 \mathrm{bcd}$ & $76,34 \mathrm{ab}$ & $71,44 \mathrm{p}$ & D bonita $1 \%=4,57$ \\
V & $60,58 \mathrm{ef}$ & $80,51 \mathrm{a}$ & $73,60 \mathrm{abc}$ & $79,44 \mathrm{a}$ & $73,53 \mathrm{p}$ & D (Kuxb) $1 \%=7,46$ \\
Rata-rata & $59,30 \mathrm{y}$ & $69,05 \mathrm{x}$ & $69,93 \mathrm{x}$ & $69,01 \mathrm{x}$ & & \\
\hline
\end{tabular}

Keterangan: nilai yang ditandai oleh huruf yang sama berarti nilai tersebut tidak berbeda secara nyata.

Tabel 7. Analisis HSD duncan interaksi antara kelas umur dan bonita terhadap dimensi lebar lingkaran tahun (mm).

\begin{tabular}{crrrrll}
\hline \multirow{2}{*}{ Kelas umur $(\mathrm{Ku})$} & \multicolumn{4}{c}{ Bonita } & \multirow{2}{*}{ Rata-rata } & \multirow{2}{*}{ Nilai duncan (D) } \\
\cline { 2 - 4 } & \multicolumn{1}{c}{3} & \multicolumn{1}{c}{3,5} & \multicolumn{1}{c}{4} & \multicolumn{1}{c}{4,5} & & \\
\hline III & $3,14 \mathrm{~cd}$ & $2,72 \mathrm{~d}$ & $2,95 \mathrm{~cd}$ & $2,74 \mathrm{~d}$ & $2,89 \mathrm{r}$ & D KU $1 \%=0,39$ \\
IV & $3,67 \mathrm{bc}$ & $3,31 \mathrm{~cd}$ & $3,41 \mathrm{~cd}$ & $4,33 \mathrm{~b}$ & $3,68 \mathrm{q}$ & D Bonita $1 \%=0,46$ \\
V & $5,75 \mathrm{a}$ & $4,37 \mathrm{~b}$ & $2,91 \mathrm{~cd}$ & $3,29 \mathrm{~cd}$ & $4,08 \mathrm{p}$ & D (Kuxb) $1 \%=0,79$ \\
Rata-rata & $4,19 \mathrm{x}$ & $3,47 \mathrm{y}$ & $3,45 \mathrm{y}$ & $3,09 \mathrm{y}$ & & \\
\hline
\end{tabular}

Keterangan: nilai yang ditandai huruf yang sama berarti tidak berbeda secara nyata

sangat nyata terhadap proporsi kayu teras, demikian pula faktor tunggal kelas umur maupun faktor bonita. Faktor posisi aksial batang berpengaruh nyata. Sementara itu, Tabel 5 memperlihatkan bahwa interaksi antara faktor kelas umur dan faktor bonita berpengaruh secara sangat nyata terhadap dimensi lebar lingkaran tahun, demikian pula faktor tunggal seperti kelas umur, bonita, faktor posisi aksial batang.

Analisis HSD Duncan dilakukan untuk mengetahui perbedaan proporsi kayu teras dan dimensi lebar lingkaran tahun di dalam interaksi antara kelas umur dan bonita. Hasilnya masingmasing disajikan di dalam Tabel 6 dan 7. Hasil analisis HSD Duncan untuk mengetahui perbedaan proporsi kayu teras dan dimensi lebar lingkaran tahun di dalam aras posisi aksial batang, disajikan masing-masing pada Tabel 8 dan 9 .

Analisis varian pada Tabel 4 memperlihatkan, bahwa interaksi antara kelas umur dan bonita berpengaruh secara sangat nyata terhadap proporsi kayu teras. Proporsi kayu teras tertinggi $(80,51 \%)$ dimiliki interaksi kelas umur $\mathrm{V}$ dan bonita 3,5, sedangkan yang terendah $(50,52 \%)$ dimiliki interaksi kelas umur $\mathrm{V}$ dan bonita 3,5. Ada kecenderungan dalam interaksi ini bahwa semakin tinggi kelas umur pohon dan semakin tinggi tingkat bonita, maka proporsi kayu teras juga semakin tinggi. Meski demikian, pola kecenderungan itu hanya berlaku bagi pohon yang dari kelas umur 5 dan kelas umur 4, tetapi kurang berlaku bagi pohon dari kelas umur 3.

Tabel 8. Pengaruh posisi aksial batang terhadap proporsi kayu teras (\%).

\begin{tabular}{lcc}
\multicolumn{1}{c}{$\begin{array}{c}\text { Posisi aksial } \\
\text { batang }\end{array}$} & Rata-rata & $\begin{array}{c}\text { Nilai Duncan } \\
5 \%\end{array}$ \\
\hline Pangkal & $69,80^{\mathrm{a}}$ & \\
Tengah & $66,06^{\mathrm{ab}}$ & 3,96 \\
Ujung & $64,61^{\mathrm{b}}$ & \\
\hline
\end{tabular}

Keterangan: nilai yang ditandai oleh huruf yang sama berarti nilai tersebut tidak berbeda secara nyata.

Tabel 9. Pengaruh posisi aksial batang terhadap dimensi lebar lingkaran tahun (mm).

\begin{tabular}{lcc}
\hline Posisi aksial batang & Rata-rata & $\begin{array}{c}\text { Nilai Duncan } \\
1 \%\end{array}$ \\
\hline Pangkal & $3,9207^{\mathrm{a}}$ & \\
Tengah & $3,4624^{\mathrm{b}}$ & 0,3954 \\
Ujung & $3,2622^{\mathrm{b}}$ & \\
\hline
\end{tabular}

Keterangan: nilai yang ditandai oleh huruf yang sama berarti nilai tersebut tidak berbeda secara nyata. 
Proporsi kayu teras membesar dari kelas umur III, dan IV serta V, yakni secara berurutan adalah 55,51 dan 71,43 serta $73,53 \%$. Hal ini dapat dipahami, mengingat bahwa pembentukan kayu teras berlangsung seiring dengan semakin bertambahnya umur pohon. Kayu teras merupakan bagian kayu di dalam batang yang sebagian besar sel-selnya telah mati dan tidak lagi berfungsi secara fisiologis bagi pohon. Di samping itu, kayu teras juga menjadi tempat utama untuk mendepositkan zat ekstraktif sekunder yang dibentuk oleh pohon. Ekstraktif merupakan salah satu wujud hasil polimerisasi yang berlangsung di dalam pohon. Polimerisasi ini menggunakan bahan baku berupa glukosa hasil proses fotosintesis yang mensintesis karbon dioksida dan air (Warren dan Adams, 2006.). Sepanjang hidupnya, pohon menyelenggarakan proses fotosintesis dan dilanjutkan dengan proses polimerisasi atas hasil fotosintesis tersebut yang antara lain menjadi zat ekstraktif. Oleh karenanya, semakin banyak umur pohon, berarti semakin banyak pula akumulasi durasi waktu yang digunakan untuk mensintesis zat ekstraktif. Proses fotosintesis yang semakin panjang, berarti juga semakin banyak hutan produksi menyerap dan menyimpan karbon dioksida. Kondisi demikian mengakibatkan kondisi lingkungan hidup juga semakin baik.

Analisis varian pada Tabel 4 memperlihatkan, bahwa bonita berpengaruh secara sangat nyata terhadap proporsi kayu teras. Tabel 7 memperlihatkan, proporsi kayu teras pada bonita 3, bonita 3,5 , bonita 4 dan bonita 4,5 secara berurutan adalah 59,30 dan 69,05 dan 69,93 serta 69,01\%. Dengan demikian, proporsi kayu teras semakin besar sejalan dengan semakin meningkatnya bonita dari bonita 3 menuju ke bonita 3,5 dan relatif konstan dari bonita 3,5 menuju ke bonita 4,5. Proporsi kayu teras pada bonita 3 berbeda secara sangat nyata terhadap kandungan kayu teras pada bonita-bonita yang lebih tinggi.

Analisis varians pada Tabel 4 juga memperlihatkan, bahwa faktor posisi aksial berpengaruh secara nyata terhadap proporsi kayu teras. Proporsi kayu teras pada bagian pangkal, tengah dan ujung batang secara berurutan adalah $69,80 \%$ dan $66,06 \%$ serta $64,61 \%$. Dengan demikian, proporsi kayu teras semakin besar seiring dengan semakin mendekatnya posisi kayu terhadap posisi pangkal batang. Uji HSD Duncan memperlihatkan, bahwa proporsi kayu teras pada bagian tengah batang tidak berbeda secara nyata terhadap proporsi pada pangkal batang dan ujung batang, tetapi proporsi pada pangkal batang berbeda secara nyata terhadap bagian ujung batang.
Zat ekstraktif merupakan zat yang disintesis dari hasil polimerisasi kimia yang menggunakan glukosa sebagai bahan dasarnya. Sintesis ini berlangsung dalam proses perjalanan waktu, sehingga semakin lama durasi waktu proses sintesis, semakin banyak zat ekstraktif yang dihasilkan. Kayu pada pangkal batang merupakan bagian kayu yang terbentuk lebih dahulu dibandingkan dengan bagian tengah dan bagian ujung batang. Oleh karenanya, bagian pangkal batang mengalami proses sintesis zat ekstraktif dengan durasi yang lebih panjang dibandingkan durasi pada bagian tengah dan ujung batang (Taylor dkk, 2002).

Analisis varians pada Tabel 5 memperlihatkan, bahwa interaksi kelas umur dan bonita berpengaruh secara sangat nyata terhadap dimensi lebar lingkaran tahun. Dimensi lebar lingkaran tahun tertinggi $(5,75 \mathrm{~mm})$ dimiliki interaksi kelas umur V dan bonita 3 , sedangkan yang terendah $(2,74 \mathrm{~mm})$ dimiliki interaksi kelas umur III dan bonita 4,5. Tabel 5 juga memperlihatkan bahwa faktor kelas umur, bonita, serta posisi longitudinal batang berpengaruh secara sangat nyata terhadap dimensi lebar lingkaran tahun.

Di dalam hal kelas umur, dimensi lebar lingkaran tahun pada kelas umur III, dan kelas umur IV serta kelas umur V secara berurutan adalah 2,89 dan 3,68 serta 4,08 $\mathrm{mm}$. Dengan demikian, dimensi lebar lingkaran tahun semakin besar seiring dengan bertambahnya umur pohon. Kenyataan ini dapat dipahami, mengingat bahwa dimensi lebar lingkaran tahun merupakan tambah tumbuh. Pola pertumbuhan pohon memiliki bentuk sigmoid, sehingga kecepatan pertumbuhan pohon pada umur muda sampai dengan umur tertentu ini semakin cepat, dan setelah melampaui umur tertentu tersebut, kecepatan pertumbuhan pohon akan menurun. Dengan demikian, pertambahan pertumbuhan pohon jati dari umur muda sampai dengan umur 45 tahun masih tergolong di dalam pola pertumbuhan pohon yang cepat. Hal ini sesuai dengan hasil penelitian Bath dan Indira (1997) serta penelitian Matumura dan Kawasaki (2011).

Di dalam hal bonita, dimensi lebar lingkaran tahun pada bonita 3, 3,5 dan 4 serta 4,5 secara berurutan adalah 4,19 dan 3,47 dan 3,45 serta 3,09 $\mathrm{mm}$. Dengan demikian, dimensi lebar lingkaran tahun semakin kecil seirama dengan semakin tingginya tingkat bonita. Kenyataan ini bersifat antagonistik dengan teori yang menyatakan bahwa bonita yang semakin rendah, maka produktivitas biologis pohon juga semakin rendah, sehingga tingkat pertumbuhannya dalam satuan waktu tertentu juga semakin rendah. Dengan demikian, ada kemungkinan bahwa tingkat bonita petak hutan 
itu telah mengalami penurunan dibandingkan dengan saat penentuannya oleh Wulffing (1932) yang disebabkan oleh adanya erosi lapisan tanah yang menurunkan tingkat kesuburannya. Hal ini berarti juga mengindikasikan adanya kemunduran kondisii kesuburan hutan dan lingkungan hidup.

Di dalam hal posisi kayu aksial batang, dimensi lebar lingkaran tahun pada posisi pangkal, dan posisi tengah dan posisi ujung batang secara berurutan adalah 3,92 dan 3,46 dan 3,26 mm. Dimensi lebar lingkaran tahun pada posisi pangkal berbeda secara sangat nyata terhadap posisi tengah dan posisi ujung, tetapi nilai pada kedua posisi yang terakhir ini tidak berbeda nyata. Dengan demikian, dimensi lebar lingkaran tahun semakin kecil seiring pergeseran posisi kayu dari pangkal menuju ke ujung batang. Kecenderungan ini memiliki persamaan dengan kecenderungan yang berkait dengan umur pohon, yakni bahwa semakin muda umur kayu semakin kecil dimensi lebar lingkaran tahun. Kayu pada bagian pangkal memiliki umur yang lebih banyak dibanding dengan kayu bagian tengah batang maupun bagian ujung batang. Dengan demikian, kayu pada bagian pangkal batang akan memiliki dimensi lebar lingkaran tahun yang lebih besar dibandingkan dengan dimensi lebar lingkaran tahun pada bagian tengah maupun ujung batang. Pola kecenderungan kadar ekstraktif dalam posisi aksial batang ini seirama dengan hasil penelitian Lukmandaru (2011).

\section{Analisis Diskriminan Kualitas Kayu.}

Berdasarkan perhitungan diperoleh nilai ratarata proporsi kayu teras $66,82 \%$ dan standar deviasinya, yaitu $12,88 \%$. Dengan menggunakan rumus kurva normal $\mathrm{Z}$, diperoleh nilai $\mathrm{Z}$ bagi setiap nilai rata-rata pada faktor-faktor: kelas umur, bonita, dan posisi akasial batang serta interaksi antara masing-masing faktor tersebut. Arah gerak sejajar dipilih sebagai acuan pola penempatan nilai $\mathrm{Z}$ masing-masing contoh uji atau unit perlakuan ke dalam kurva normal nilai $Z$. Arah gerak sejajar ini menyatakan bahwa semakin tinggi nilai $\mathrm{Z}$ contoh uji berarti semakin tinggi pula peringkat kualitas kayu. Pemilihan ini didasarkan pada pola keterkaitan yang positif antara proporsi kayu teras dan peringkat kualitas kayu, yaitu semakin tinggi proporsi kayu teras semakin tinggi peringkat kualitas kayu. Pola keterkaitan tersebut didukung oleh hasil penelitian Lukmandaru (2011), yang menyatakan bahwa semakin tinggi proporsi kayu teras berefek pada semakin tinggi tingkat ketahanan kayu terhadap serangan rayap dan semakin tinggi pula kualitas kayu sebagai bahan konstruksi.

Sementara itu, berdasarkan perhitungan diperoleh nilai rata-rata lebar lingkaran tahun, yaitu
3,55 $\mathrm{mm}$, dan standar deviasinya, yaitu 1,19 $\mathrm{mm}$. Dengan menggunakan rumus $Z$, diperoleh hasil perhitungan nilai $Z$ bagi setiap nilai rata-rata pada faktor-faktor: kelas umur, bonita, dan posisi aksial batang serta interaksinya. Arah gerak berlawanan dipilih untuk digunakan sebagai acuan pola penempatan masing-masing nilai $\mathrm{Z}$ ke dalam kurva normal nilai $Z$. Arah gerak berlawanan ini menyatakan bahwa semakin tinggi nilai $\mathrm{Z}$ berarti semakin rendah peringkat kualitas kayu. Pemilihan ini didasarkan pada pola keterkaitan negatif antara lebar lingkaran tahun dan peringkat kualitas, yaitu semakin besar dimensi lebar lingkaran tahun akan berefek pada semakin rendah peringkat kualitas kayu. Pola keterkaitan ini sesuai dengan Bath dan Indira (1997) yang menyatakan bahwa lingkaran tahun yang lebar sangat merugikan bagi produk yang berupa kayu solid, sehingga lingkaran tahun yang lebar tidak sesuai baginya.

Berdasarkan penempatan tersebut, maka dapat diketahui besarnya nilai peringkat kualitas kayu bagi setiap nilai rata-rata yang dimiliki oleh setiap faktor, yakni kelas umur, bonita, dan posisi aksial batang serta setiap interaksi yang terjadi antara ketiga faktor tersebut. Hasil pemeringkatan kualitas kayu berdasarkan parameter proposi kayu teras dan dimensi lebar lingkaran tahun disajikan di dalam Lampiran 1.

Berdasarkan Lampiran 1, terlihat bahwa peringkat kualitas kayu yang tertinggi dan yang terendah secara berurutan adalah: (1) interaksi tiga faktor yakni kelas umur $\mathrm{V}$, bonita 4 dan posisi tengah batang, atau interaksi kelas umur $\mathrm{V}$, bonita 4,5 dan posisi ujung dengan peringkat kelas 2, sedang interaksi kelas umur $\mathrm{V}$, bonita 3 dan posisi ujung batang dengan peringkat kelas 4 , (2) interaksi dua faktor pada (a) kelas umur $\mathrm{V}$ dan bonita 4 dengan peringkat 2 , sedang interaksi kelas umur $\mathrm{V}$ dan bonita 3 dengan peringkat 4 . (b) kelas umur IV dan posisi tengah dengan peringkat 2 , sedang interaksi kelas umur $\mathrm{V}$ dan posisi pangkal dengan peringkat 3,5 (c) bonita 4 dan posisi pangkal dengan peringkat 2,5, sedang interaksi bonita 3 dan posisi ujung dengan peringkat 3,5. (3) faktor tunggal pada (a) kelas umur $\mathrm{V}$ dengan peringkat tertinggi 2,5, (b) bonita 3,5 dan 4 dan 4,5 dengan peringkat tertinggi 3 , (c) posisi pangkal, tengah dan ujung dengan peringkat yang sama yaitu 3 . Dengan demikian, terbukti bahwa tingkat kualitas kayu tertinggi dihasilkan dari penebangan hutan produksi yang semakin tua umurnya ketika ditebang, yakni kelasu umur V. Pada gilirannya, penebangan hutan produksi pada kelas umur tua ini juga berakibat positif bagi kelestarian lingkungan hidup 


\section{KESIMPULAN}

Proporsi kayu teras dan lebar lingkaran tahun tidak dipengaruhi oleh interaksi tiga faktor yakni kelas umur, bonita dan posisi aksial batang, tetapi dipengaruhi oleh interaksi dua faktor, yakni kelas umur dan bonita. Interaksi kelas umur $\mathrm{V}$ dan bonita 3,5 menghasilkan kayu mengandung teras tertinggi, sebaliknya interaksi kelas umur III dan bonita 3,5 menghasilkan yang terendah. Interaksi kelas umur $\mathrm{V}$ dan bonita 3 menghasilkan kayu dengan lingkaran tahun terlebar, sedang interaksi kelas umur III dan bonita 4,5 menghasilkan yang tersempit. Kayu yang posisinya semakin mendekat pada pangkal batang memiliki proporsi kayu teras semakin besar, tetapi dimensi lingkaran tahun semakin kecil. Pemanenan hutan produksi pada kelas umur $\mathrm{V}$ menghasilkan kayu dengan kualitas tinggi, berumur pakai lama dan mendukung perbaikan kondisi lingkungan hidup.

Disarankan, agar kelas umur, tingkat bonita dan posisi kayu di dalam batang dipertimbangkan ketika memilih kayu jati sebagai bahan memproduksi furnitur. Interaksi kelas umur dan bonita berpengaruh terhadap kualitas kayu jatisebagai bahan mebel.

\section{DAFTAR PUSTAKA}

Bath, K.M., dan Indira, E.P., 1997. Effect of Faster Growth on Timber Quality of Teak. Kerala Forest Research Institute. Peechi, Thrissur.

Darwis, A., Hartono, R., dan Hidayat, S.S., 2005. Presentase Kayu Teras dan Kayu Jati (Tectona grandis L.f.). Jurnal Ilmu dan Teknologi Kayu Tropis 3(1):6-8.

Etele, C., dan Magoss, E., 2013. Mechanics of Wood Machining. Second Edition. Springer. Heidelberg.

Gadas, S.R., 2005. Sisi Pasokan Hutan Tanaman. Makalah Lokakarya Restrukturisasi Industri Kehutanan Indonesia. Century Park, 1 Desember 2005. Jakarta.

Githiomi, J.K., dan Dougal E., 2012. Analysis of Heartwood - Sapwood Demarcation Methods and Variation of Sapwood and Heartwood within and Between 15 Year Old Plantation Grown Eucalyptus Regnans. Int. J. Applied Sci. \& Technol., 2(8):63-67.

Lukmandaru, G. 2011. Variablity in the Natural Termite Resistence of Plantation Teak Wood and Its Relation With Wood Extractive
Contents and Its Color Properties. J. Forestry Res. 8(1):17-31.

Matsumura, J., dan Kawasaki, Y., 2011. Effect of Rotation Age on Wood Quality of Teak (Tectona grandis Linn f) Planted in Indonesia, Asia Sustainable Local Resource Management Workshop.

Moore, J.R., Lyon, A.J., Searles, G.J. dan Vihermaa, L.E. 2009. The Effects of Site and Stand Factors on the Tree and Wood Quality of Sitka Spruce Growing in the United Kingdom. Silva Fennica 43(3):383-396.

Prayitno, 2005. Pertumbuhan Pohon dan Kualitas Kayu. Fakultas Kehutanan Universitas Gadjah Mada. Yogyakarta.

Seno, A., 2008. Pengembangan Industri Furniture di Indonesia. Makalah workshop Pengembangan Keunggulan Lokal Program Studi Teknologi Hasil Hutan. Fakultas Kehutanan Universitas Gadjah Mada, Yogyakarta.

Tan, Y.E., Lim, N., Josue, J., dan Gan, K.S., 2007. Improving Utilization Value Adding of Plantation Timbers from Sustainable Sources in Malaysia. Makalah The IUFRO All Division 5 Meeting. Taipei.

Taylor, A.M., Garner B.L., dan Morrell, J.J., 2012. Heartwood Fornation and Natural Durabiliity, A Review. Wood and Fiber Science Journal 34(4):587-611.

Wanneng, P., 2011. Wood Property Assessment of Teak (Tectona grandis Linn. F) Plantation of Different Ages Grown in Lao PDR. Theses, School of Forest and Ecosystem Science, The University of Melbourne, Melbourne.

Warren C.R., dan Adams M.A., 2006. Internal Conductance Does Not Scale with Photosynthetic Capacity: Implications for Carbon Isotope Discrimination and the Economics of Water and Nitrogen Use in Photosynthesis. Plant, Cell Environ. 29:192201.

Wulffing, W., 1932. Tabel Tegakan untuk Tanaman Jati. Pengumuman Singkat Balai Penelitian Kehutanan No. 63. Terjemahan oleh Hardjosudiro, S.,. Fakultas Kehutanan Universitas Gadjah Mada. Yogyakarta.

Zakamouline, V., dan Koekebakker, S., 2008. A Generalization of the Mean-Variance Analysis.

Zobel, B.J., dan Buijtenen, J.P., 1989. Wood Variation: Its Causes and Control. SpringerVerlag, Berlin. 
Lampiran 1. Hasil pemeringkatan kelas kualitas.

\begin{tabular}{|c|c|c|c|c|c|c|c|c|}
\hline \multirow[t]{2}{*}{ No urut } & \multirow{2}{*}{$\begin{array}{c}\text { Faktor tunggal } \\
\text { dan } \\
\text { interaksinya }\end{array}$} & \multicolumn{3}{|c|}{ Proporsi teras } & \multicolumn{3}{|c|}{ Lebar lingkaran tahun } & \multirow{2}{*}{$\begin{array}{l}\text { Rata-rata kelas } \\
\text { kualitas kayu }\end{array}$} \\
\hline & & $\begin{array}{c}\text { Rata-rata } \\
(\%)\end{array}$ & Nilai Z & $\begin{array}{c}\text { Kelas } \\
\text { kualitas }\end{array}$ & $\begin{array}{c}\begin{array}{c}\text { Rata-rata } \\
(\mathrm{mm})\end{array} \\
\end{array}$ & Nilai Z & $\begin{array}{c}\text { Kelas } \\
\text { kualitas }\end{array}$ & \\
\hline 1 & KU III & 55,507 & $-0,879$ & 4 & 2,886 & $-0,559$ & 2 & 3 \\
\hline 2 & KU IV & 71,435 & 0,358 & 3 & 3,680 & 0,111 & 3 & 3 \\
\hline 3 & KU V & 73,533 & 0,521 & 2 & 4,078 & 0,447 & 3 & 2,5 \\
\hline 4 & Bon 3 & 59,303 & $-0,584$ & 4 & 4,188 & 0,539 & 4 & 4 \\
\hline 5 & Bon 3,5 & 69,053 & 0,173 & 3 & 3,468 & $-0,068$ & 3 & 3 \\
\hline 6 & Bon 4 & 69,929 & 0,241 & 3 & 3,087 & $-0,389$ & 3 & 3 \\
\hline 7 & Bon 4,5 & 69,015 & 0,170 & 3 & 3,451 & $-0,082$ & 3 & 3 \\
\hline 8 & Pangkal (P) & 69,801 & 0,231 & 3 & 3,921 & 0,314 & 3 & 3 \\
\hline 9 & Tengah (T) & 66,065 & $-0,059$ & 3 & 3,462 & $-0,073$ & 3 & 3 \\
\hline 10 & Ujung (U) & 64,609 & $-0,172$ & 3 & 3,262 & $-0,242$ & 3 & 3 \\
\hline 11 & (IIIx3) & 53,977 & $-0,998$ & 4 & 3,139 & $-0,345$ & 3 & 3,5 \\
\hline 12 & (IIIx3,5) & 50,525 & $-1,266$ & 4 & 2,722 & $-0,697$ & 2 & 3 \\
\hline 13 & (IIIx4) & 66,257 & $-0,044$ & 3 & 2,949 & $-0,506$ & 2 & 2,5 \\
\hline 14 & (IIIx 4,5) & 51,271 & $-1,208$ & 4 & 2,736 & $-0,685$ & 2 & 3 \\
\hline 15 & (IVx3) & 63,352 & $-0,270$ & 3 & 3,675 & 0,107 & 3 & 3 \\
\hline 16 & $(\mathrm{IV} \times 3,5)$ & 76,121 & 0,722 & 2 & 3,314 & $-0,198$ & 3 & 2,5 \\
\hline 17 & $(\mathrm{IVx} 4)$ & 69,927 & 0,241 & 3 & 3,407 & $-0,119$ & 3 & 3 \\
\hline 18 & $(\operatorname{IVx} 4,5)$ & 76,338 & 0,739 & 2 & 4,326 & 0,656 & 4 & 3 \\
\hline 19 & $(\mathrm{~V} \times 3)$ & 60,581 & $-0,485$ & 3 & 5,75 & 1,857 & 5 & 4 \\
\hline 20 & $(\mathrm{~V} \times 3,5)$ & 80,512 & 1,063 & 2 & 4,369 & 0,692 & 4 & 3 \\
\hline 21 & $(\mathrm{~V} \times 4)$ & 73,603 & 0,526 & 2 & 2,905 & $-0,543$ & 2 & 2 \\
\hline 22 & $(\mathrm{Vx} 4,5)$ & 79,436 & 0,979 & 2 & 3,289 & $-0,219$ & 3 & 2,5 \\
\hline 23 & (IIIxP) & 58,909 & $-0,615$ & 4 & 3,363 & $-0,156$ & 3 & 3,5 \\
\hline 24 & (IIIxT) & 54,149 & $-0,984$ & 4 & 2,785 & $-0,644$ & 2 & 3 \\
\hline 25 & (IIIxU) & 53,465 & $-1,038$ & 4 & 2,511 & $-0,875$ & 2 & 3 \\
\hline 26 & (IVxP) & 73,752 & 0,538 & 2 & 3,905 & 0,301 & 3 & 2,5 \\
\hline 27 & (IVxT) & 71,365 & 0,353 & 3 & 3,643 & 0,080 & 3 & 3 \\
\hline 28 & (IVxU) & 69,187 & 0,183 & 3 & 3,492 & -0.048 & 3 & 3 \\
\hline 29 & $(\mathrm{VxP})$ & 76,743 & 0,770 & 2 & 4,494 & 0,797 & 4 & 3 \\
\hline 30 & $(\mathrm{VxT})$ & 72,68 & 0,455 & 3 & 3,959 & 0,346 & 3 & 3 \\
\hline 31 & $(V x U)$ & 71,176 & 0,338 & 3 & 3,783 & 0,198 & 3 & 3 \\
\hline 32 & $(3 \times P)$ & 61,837 & $-0,387$ & 3 & 4,835 & 1,085 & 4 & 3,5 \\
\hline 33 & $(3 \times T)$ & 58,071 & $-0,680$ & 4 & 3,88 & 0,280 & 3 & 3,5 \\
\hline 34 & $(3 \times U)$ & 58,003 & $-0,685$ & 4 & 3,848 & 0,253 & 3 & 3,5 \\
\hline 35 & $(3,5 \times P)$ & 71,556 & 0,367 & 3 & 3,649 & 0,085 & 3 & 3 \\
\hline 36 & $(3,5 \times \mathrm{T})$ & 67,353 & 0,041 & 3 & 3,442 & $-0,090$ & 3 & 3 \\
\hline 37 & $(3,5 \times U)$ & 68,25 & 0,111 & 3 & 3,313 & $-0,199$ & 3 & 3 \\
\hline 38 & $(4 \mathrm{xP})$ & 73,449 & 0,514 & 2 & 3,377 & $-0,145$ & 3 & 2,5 \\
\hline 39 & $(4 \times T)$ & 70,241 & 0,265 & 3 & 3,009 & $-0,455$ & 3 & 3 \\
\hline 40 & $(4 x U)$ & 66,097 & $-0,057$ & 3 & 2,874 & $-0,569$ & 2 & 2,5 \\
\hline 41 & $(4,5 \times P)$ & 72,364 & 0,430 & 3 & 3,821 & 0,230 & 3 & 3 \\
\hline 42 & $(4,5 \times T)$ & 68,594 & 0,137 & 3 & 3,518 & $-0,026$ & 3 & 3 \\
\hline 43 & $(4,5 x U)$ & 66,087 & $-0,057$ & 3 & 3,013 & $-0,452$ & 3 & 3 \\
\hline 44 & (IIIx $3 x P$ ) & 55,00 & $-0,918$ & 4 & 3,641 & 0,078 & 3 & 3,5 \\
\hline 45 & (IIIx3xT) & 52,64 & $-1,102$ & 4 & 3,13 & $-0,353$ & 3 & 3,5 \\
\hline 46 & (IIIx $3 \times U)$ & 54,29 & $-0,974$ & 4 & 2,645 & $-0,762$ & 2 & 3 \\
\hline 47 & (IIIx $3,5 \mathrm{xP})$ & 53,72 & $-1,018$ & 4 & 3,108 & $-0,371$ & 3 & 3,5 \\
\hline 48 & (IIIx $3,5 \times T)$ & 48,34 & $-1,436$ & 4 & 2,769 & $-0,657$ & 2 & 3 \\
\hline 49 & (IIIx3,5xU) & 49,52 & $-1,344$ & 4 & 2,289 & $-1,062$ & 2 & 3 \\
\hline 50 & (IIIx4xP) & 70,65 & 0,297 & 3 & 3,089 & $-0,387$ & 3 & 3 \\
\hline 51 & (IIIx4xT) & 63,08 & $-0,291$ & 3 & 2,764 & $-0,662$ & 2 & 2,5 \\
\hline 52 & (IIIx4xU) & 65,05 & $-0,138$ & 3 & 2,993 & $-0,468$ & 3 & 3 \\
\hline 53 & (IIIx4,5xP) & 56,27 & $-0,820$ & 4 & 3,613 & 0,054 & 3 & 3,5 \\
\hline 54 & (IIIx4,5xT) & 52,52 & $-1,111$ & 4 & 2,477 & $-0,904$ & 2 & 3 \\
\hline 55 & (IIIx4,5xU) & 45,00 & $-1,695$ & 5 & 2,188 & $-1,147$ & 2 & 3,5 \\
\hline 56 & $(\mathrm{IV} \times 3 \times \mathrm{P})$ & 64,01 & $-0,219$ & 3 & 3,814 & 0,224 & 3 & 3 \\
\hline 57 & $(\mathrm{IV} \times 3 \times \mathrm{T})$ & 63,36 & $-0,269$ & 3 & 3,534 & $-0,012$ & 3 & 3 \\
\hline 58 & (IVx3xU) & 62,68 & $-0,322$ & 3 & 3,677 & 0,108 & 3 & 3 \\
\hline 59 & (IVx3,5xP) & 79,83 & 1,010 & 2 & 3,495 & $-0,045$ & 3 & 2,5 \\
\hline 60 & $(\mathrm{IVx} 3,5 \times \mathrm{T})$ & 74.07 & 0,563 & 2 & 3,288 & $-0,220$ & 3 & 2,5 \\
\hline 61 & $(\mathrm{IV} 33,5 \times \mathrm{X})$ & 74,47 & 0,594 & 2 & 3,16 & $-0,328$ & 3 & 2,5 \\
\hline 62 & $(\mathrm{IVx} 4 \mathrm{xP})$ & 73,42 & 0,512 & 2 & 3,736 & 0,158 & 3 & 2,5 \\
\hline 63 & $(\mathrm{IV} \times 4 \times \mathrm{T})$ & 72,77 & 0,462 & 3 & 3,397 & $-0,128$ & 3 & 3 \\
\hline 64 & $(\mathrm{IV} x 4 \mathrm{xU})$ & 63,59 & $-0,251$ & 3 & 3,086 & $-0,390$ & 3 & 3 \\
\hline
\end{tabular}




\begin{tabular}{|c|c|c|c|c|c|c|c|c|c|}
\hline \multirow[t]{2}{*}{ No urut } & \multirow{2}{*}{$\begin{array}{c}\text { Faktor tunggal } \\
\text { dan } \\
\text { interaksinya }\end{array}$} & \multicolumn{3}{|c|}{ Proporsi teras } & \multicolumn{3}{|c|}{ Lebar lingkaran tahun } & \multirow{2}{*}{\multicolumn{2}{|c|}{$\begin{array}{c}\text { Rata-rata kelas } \\
\text { kualitas kayu }\end{array}$}} \\
\hline & & $\begin{array}{c}\text { Rata-rata } \\
(\%)\end{array}$ & Nilai Z & $\begin{array}{c}\text { Kelas } \\
\text { kualitas }\end{array}$ & $\begin{array}{l}\text { Rata-rata } \\
(\mathrm{mm})\end{array}$ & Nilai Z & $\begin{array}{c}\text { Kelas } \\
\text { kualitas }\end{array}$ & & \\
\hline 65 & $(\mathrm{IVx} 4,5 \times \mathrm{x})$ & 77,75 & 0,848 & 2 & 4,575 & 0,866 & 4 & 3 & \\
\hline 66 & $(\mathrm{IVx} 4,5 \times \mathrm{T})$ & 75,26 & 0,655 & 2 & 4,354 & 0,679 & 4 & 3 & \\
\hline 67 & $(\mathrm{IVx} 4,5 \mathrm{xU})$ & 76,00 & 0,713 & 2 & 4,047 & 0,420 & 3 & 2,5 & \\
\hline 68 & $(\mathrm{~V} \times 3 \times \mathrm{P})$ & 66,50 & $-0,025$ & 3 & 7,051 & 2,954 & 5 & 4 & \\
\hline 69 & $(\mathrm{~V} \times 3 \times \mathrm{T})$ & 58,21 & $-0,669$ & 4 & 4,976 & 1,204 & 4 & 4 & \\
\hline 70 & $(\mathrm{~V} \times 3 \times \mathrm{U})$ & 57,03 & $-0,761$ & 4 & 5,223 & 1,412 & 4 & 4 & \\
\hline 71 & $(\mathrm{~V} \times 3,5 \times \mathrm{P})$ & 81,13 & 1,111 & 2 & 4,345 & 0,672 & 4 & 3 & \\
\hline 72 & $(\mathrm{~V} \times 3,5 \times \mathrm{T})$ & 79,66 & 0,997 & 2 & 4,271 & 0,609 & 4 & 3 & \\
\hline 73 & $(\mathrm{~V} \times 3,5 \times U)$ & 80,76 & 1,082 & 2 & 4,491 & 0.795 & 4 & 3 & \\
\hline 74 & $(\mathrm{Vx} 4 \mathrm{xP})$ & 76,28 & 0,734 & 2 & 3,306 & $-0,204$ & 3 & 2,5 & \\
\hline 75 & $(\mathrm{~V} \times 4 \times \mathrm{T})$ & 74,88 & 0,626 & 2 & 2,865 & $-0,576$ & 2 & 2 & \\
\hline 76 & $(\mathrm{~V} \times 4 \times \mathrm{x})$ & 69,65 & 0,219 & 3 & 2,544 & $-0,847$ & 2 & 2,5 & \\
\hline 77 & $(\mathrm{Vx} 4,5 \mathrm{xP})$ & 83,07 & 1,262 & 2 & 3,273 & $-0,232$ & 3 & 2,5 & \\
\hline 78 & $(\mathrm{Vx} 4,5 \times \mathrm{T})$ & 77,97 & 0,866 & 2 & 3,723 & 0,147 & 3 & 2,5 & \\
\hline 79 & $(\mathrm{Vx} 4,5 \mathrm{xU})$ & 77,26 & 0,810 & 2 & 2,873 & $-0,570$ & 2 & 2 & \\
\hline Rerata & 66,82 & & 3,548 & & & & & & \\
\hline $\mathrm{SD}$ & 12,88 & & 1,186 & & & & & & \\
\hline \multicolumn{10}{|c|}{ Keterangan } \\
\hline \multicolumn{2}{|c|}{ Parameter } & Wilayah Z & & $\mathrm{Z}<-1,5$ & $-1,5<Z<-0,51$ & $-0,5$ & $<\mathrm{Z}<0.5$ & $0,51<\mathrm{Z}<1,5$ & $\mathrm{Z}>1,5$ \\
\hline \multicolumn{2}{|c|}{ Proporsi kayu teras } & $\begin{array}{l}\text { Peringkat } \\
\text { Kualitas } \\
\text { Peringkat }\end{array}$ & & 5 & 4 & & 3 & 2 & 1 \\
\hline \multicolumn{2}{|c|}{ Lebar lingkaran tahun } & Kualitas & & 1 & 2 & & 3 & 4 & 5 \\
\hline
\end{tabular}

